\title{
National Case Law as a Generator of International Refugee Law: Rectifying an Imbalance within UNHCR Guidelines on International Protection
}

Cecilia M. Bailliet

Follow this and additional works at: https://scholarlycommons.law.emory.edu/eilr-recent-developments

\section{Recommended Citation}

Cecilia M. Bailliet, National Case Law as a Generator of International Refugee Law: Rectifying an Imbalance within UNHCR Guidelines on International Protection, 29 Emory Int'I L. Rev. Recent Dev. 2059 (2015).

Available at: https://scholarlycommons.law.emory.edu/eilr-recent-developments/26

This Essay is brought to you for free and open access by the Journals at Emory Law Scholarly Commons. It has been accepted for inclusion in Emory International Law Review Recent Developments by an authorized administrator of Emory Law Scholarly Commons. For more information, please contact law-scholarlycommons@emory.edu. 


\title{
NATIONAL CASE LAW AS A GENERATOR OF INTERNATIONAL REFUGEE LAW: RECTIFYING AN IMBALANCE WITHIN UNHCR GUIDELINES ON INTERNATIONAL PROTECTION
}

\author{
Cecilia M. Bailliet ${ }^{*}$
}

\begin{abstract}
This Article seeks to evaluate UNHCR Guidelines on International Protection in order to examine whether there are discrepancies in the citation of national case law. Part I pursues quantitative analysis of UNHCR's references to national case law in its guidelines. It is suggested that there are two main problems: first, the absence of reference to national case law in some guidelines and second, the dominance of common law/English-language national decisions in other guidelines which renders UNHCR output subject to legitimacy challenges as it seeks to provide objective guidance on interpretation of the 1951 Convention on the Status of Refugees. It also quantifies and discusses the nature of reference to case law from international human rights and criminal tribunals within UNHCR guidelines. Part II presents an alternative view on the importance of transnational judicial dialogues within Refugee Law, using as a case example the treatment of conscientious objectors seeking asylum in different national jurisdictions as juxtaposed to the UNHCR guidelines on military service. Part III assesses whether the Background Papers demonstrate parallel citation lacunae or biases. Part IV offers a conclusion calling for reform of UNHCR's Department of International Protection in order to improve the compilation and reference to national case law by UNHCR in its soft law guidelines and policy documents, as well as improving the transparency of UNHCR's Refugee Status Determination system so as to improve the legitimacy of the evolution of international refugee law.
\end{abstract}

* Professor, Department of Public \& International Law/PluriCourts University of Oslo, Norway. This Article is an expanded version of a speech I gave at the 2014 European Society of International Law conference. I warmly appreciate the thorough research assistance of Laura Letourneau-Tremblay, as well as the helpful information provided by Frances Nicholson and Alice Edwards at UNHCR. 


\section{INTRODUCTION}

The evolution of International Refugee Law is marked by the fact that it lacks an international refugee court to provide authoritative statements on the interpretation of the 1951 Convention on the Status of Refugees. ${ }^{1}$ Instead, it relies on soft law guidelines produced by the United Nations High Commissioner for Refugees (UNHCR), case law emitted at the national level by refugee tribunals, administrative agencies, and other courts; as well as decisions from international courts from other regimes, such as human rights or international criminal law. There are initiatives to promote transnational judicial dialogues, such as the International Association of Refugee Law Judges, but this has been criticized as having "no real impact" at the European level. ${ }^{2}$

In 2000, UNHCR convened Global Consultations on International Protection with academic experts, governments, the International Association of Refugee Law Judges, legal practitioners, and NGOs in order to pursue "greater clarity and coherence of interpretation" of the 1951 Convention on the Status of Refugees. ${ }^{3}$ The papers commissioned for the Global Consultations served as background notes for the elaboration of soft-law guidelines. ${ }^{4}$ Volker Türk, the Director of International Protection at UNHCR HQ, noted that "[ $\mathrm{t}]$ heir purpose was to take stock of the state of law and practice in these areas, to consolidate the various positions taken and to develop concrete recommendations on the way forward to achieve more consistent understandings of these various interpretative issues." The Background Papers led to the publication of Guidelines on International Protection, which are characterized as issued pursuant to UNCHR's supervisory role under its Statute and the 1951 Convention. ${ }^{6}$ At present, UNHCR has produced ten official Guidelines on International Protection addressing gender-related persecution, "membership of a particular social group", cessation of refugee

\footnotetext{
1 Convention Relating to the Status of Refugees, July 28, 1951, 189 U.N.T.S. 150.

2 See The Limits of Transnational Law: Refugee Law, Policy Harmonization and Judicial Dialogue in the European Union 9 (Guy S. Goodwin-Gill \& Helene Lambert eds., 2010).

3 See Refugee Protection in International Law: UNHCR's Global Consultations on International Protection xv (Erika Feller, Volker Türk \& Frances Nicholson eds., 2003); Volker Türk, Introductory Note to UNHCR Guidelines on International Protection, 15 INT'L J. REFUGEE L. 303, 303 (2003).

4 Volker Türk, supra note 3, at 303-04.

5 Id. at 303.

6 Refugee Protection in International Law, supra note 3, at 9 (citing the Statute of the Office of the United Nations High Comm'r for Refugees, G.A. Res.428 (V), U.N. Doc. A/RES/428 (V) (Dec. 14, 1950); Convention Relating to the Status of Refugees art. 35, July 28, 1951, 189 U.N.T.S. 150; and Protocol Relating to the Status of Refugees art. 2, Oct. 4, 1967, 606 U.N.T.S. 267)).
} 
status, internal flight alternative, exclusion clauses (for persons who have committed crimes against peace, war crimes, crimes against humanity, or serious non-political crimes), religion-based claims, victims of trafficking, child asylum claims, claims based on sexual orientation and/or gender identity, and claims related to military service. ${ }^{7}$ These issues present challenging interpretation dilemmas according to the 1951 Convention on the Status of Refugees, and the guidelines are intended to provide 'UNHCR's authoritative legal position on the various interpretive issues that arise and to provide legal guidance for governments and [legal] practitioners."

Türk explains that the UNHCR is a type of treaty monitoring body of the 1951 Convention and that the "issuance of the Guidelines has been preceded by an analysis of State practice (including jurisprudence) and an examination of the applicable international legal framework." According to UNHCR, they are intended to have an authoritative status because of the process behind the drafting of the guidelines, consisting of the production of a Background Note, a Consultation, and an Expert Roundtable. The Roundtables include representatives from governments, NGOs, "academia, the judiciary, and the legal profession," producing Summary Conclusions which reflect the discussions held. ${ }^{10}$ The Guidelines on International Protection are linked to the 1979 UNHCR Handbook on Procedures and Criteria for Determining Refugee Status (hereinafter Handbook), which was intended to provide states with guidance on the meaning and interpretation of the 1951 Convention. $^{11}$ However, the Handbook itself has been subject to debate as to whether it is to be viewed as "persuasive, discretionary or mandatory."12 Indeed, Anthony M. North and Joyce Chia note that as pertaining to the Handbook, "[i]t remains true, at least in Australian courts, that where there is a conflict of opinion,

7 See generally, U.N. High Comm'r for Refugees (UNHCR), Handbook and Guidelines on Procedures and Criteria for Determining Refugee Status under the 1951 Convention and the 1967 Protocol Relating to the Status of Refugees, 77-147, U.N. Doc HCR/1P/4/ENG/REV. 3 (Dec. 2011), available at http:// www.refworld.org/docid/4f33c8d92.html [hereinafter Handbook and Guidelines on the 1951 Convention and the 1967 Protocol].

8 Türk, supra note 3, at 304. The UNHCR Statute sets forth in paragraph 8 that "the High Commissioner shall promote the conclusion and ratification of international conventions for the protection of refugees, supervise their application and propose amendments thereto." Statute of the Office of the United Nations High Comm'r for Refugees, supra note 6, para. 8(a).

9 Türk, supra note 3, at 304.

10 Refugee Protection in International LaW, supra note 3, at 9.

11 Handbook and Guidelines on the 1951 Convention and the 1967 Protocol, supra note 7, at 1-2.

12 Satvinder Singh Juss, The UNHCR Handbook and the Interface between 'Soft Law' and 'Hard Law' in International Refugee Law, in CONTEMPORARY ISSUES IN REFUGEE LAW 31, 38 (Satvinder Singh Juss \& Colin Harvey eds., 2013). 
greater weight is generally accorded to decisions of other common law courts and learned commentators." ${ }^{13}$ Regarding the Guidelines on International Protection, they conclude that they have had some impact in common law jurisdictions, including Australia, the United States, and Canada, but have been endorsed most enthusiastically so far by the United Kingdom. ${ }^{14}$ They call for a global character interpretation of the 1951 Convention that will promote consistency. ${ }^{15}$ Hence, it is necessary to review the Guidelines on International Protection to examine whether they can be characterized as reflecting a global character. $^{16}$

Goodwin-Gill confirms that the supervisory role of UNHCR has been interpreted as follows:

[The] UNHCR does not have binding authority to interpret the 1951 Convention and, even though states have asked UNHCR to provide "guidance", they and national courts have emphasised, perhaps all too often, that such views are not binding.

If guidelines are to be treated as authoritative - and courts know full well that they are not "bound" by what UNHCR may say-then the methodology needs very careful consideration. First, this means identifying novel protection needs with some precision - the area or issue should be one in which guidance is evidently necessary, and where clarification or development of the refugee definition or other provisions of the Convention is feasible. Second, guidelines must be soundly based in basic principles of international law, particularly those related to the interpretation of treaties and the development of customary international law. Third, UNHCR need to recognize, and closely analyse and understand, even if they do not adopt, the reasoning and approaches of national and international courts, as well

13 Anthony M. North \& Joyce Chia, Towards convergence in the interpretation of the Refugee Convention: A proposal for the establishment of an International Judicial Commission for Refugees, in THE UNHCR AND THE SUPERVISION OF INTERNATIONAL REFUGEE LAW 214, 236 (James C. Simeon ed., 2013).

14 Id. at 226-27.

15 See id. at 214-15.

16 See id. They also advocate the creation of an International Judicial Commission for Refugees. Id. Indeed, Jane McAdam confirms that Australian courts make little reference to EU law, more often refer to jurisprudence from the United Kingdom, New Zealand, and Canada (with exception of cases influenced by the Canadian Charter of Rights and Freedoms which has no parallel in Australia) to explore treaty interpretation. Jane McAdam, Migrating Laws? The 'plagiaristic dialogue' between Europe and Australia, in THE GLOBAL REACH OF EUROPEAN REFUGEE LAW 25 (Helene Lambert, Jane McAdam \& Maryellen Fullerton eds., 2013) . 
as the views and practices of other stakeholders in refugee protection. $^{17}$

This paper will seek to discuss discrepancies in citation of national case law in the evolution of refugee law within UNHCR Guidelines on International Protection. Part I pursues a quantitative analysis of UNHCR's references to national case law in its guidelines. It is suggested that there are two main problems: first, the absence of reference to national case law in some guidelines and second, the dominance of common law/English-language national decisions in other guidelines which renders UNHCR output subject to legitimacy challenges as it seeks to provide objective guidance on interpretation of the 1951 Convention on the Status of Refugees. It also quantifies and discusses the nature of reference to case law from international human rights and criminal tribunals within UNHCR guidelines. Part II presents an alternative view on the importance of transnational judicial dialogues within Refugee Law, using as a case example the treatment of conscientious objectors seeking asylum in different national jurisdictions as juxtaposed to the UNHCR guidelines on military service. Part III assesses whether the Background Papers demonstrate parallel citation lacunae or biases. Part IV offers a conclusion calling for reform of UNHCR's Department of International Protection in order to improve the compilation and reference to national case law by UNHCR in its soft law guidelines and policy documents, as well as improving the transparency of UNHCR's Refugee Status Determination system so as to improve the legitimacy of the evolution of international refugee law.

As a caveat, it should be noted that there are procedural variances in production of the Guidelines on International Protection, for example the consultation on Sexual Orientation and Gender occurred after the guideline was issued. The guideline on victims of trafficking was issued without an expert meeting or a Background Paper. ${ }^{18}$ UNHCR also produces additional guidance notes on particular topics (such as on victims of organized criminal gangs, blood feuds, female genital mutilation, etc.) but they are considered to be less authoritative than the Guidelines on International Protection due to the fact that a simpler process is pursued. ${ }^{19}$ Nevertheless, because of the special

17 Guy S. Goodwin-Gill, The Dynamic of International Refugee Law, 25 INT'L J. REFUGEE L. 651, 655 (2014).

18 See UNHCR, Guidelines on International Protection No. 7: The application of Article 1A(2) of the 1951 Convention and/or 1967 Protocol relating to the Status of Refugees to victims of trafficking and persons at risk of being trafficked, U.N. Doc. HCR/GIP/06/07 (Apr. 7, 2002).

19 United Nations, UNHCR Guidance Note ON Refugee Claims Relating to Sexual ORIENTATION AND GENDER IDENTITY 2 (2006), http://www.refworld.org/docid/48abd5660.html. 
status of the Guidelines, the representativeness of their case citations is of particular interest.

\section{REFERENCE TO NATIONAL AND INTERNATIONAL CASE LAW WITHIN UNHCR GUIDELINES}

Review of the Guidelines found a clear bias in favor of citation of common law jurisdictions over civil law jurisdictions, and no citations from the developing world whatsoever. In terms of use of reference to the jurisprudence of international tribunals, UNHCR Guidelines on International Protection have turned to these institutions for progressive analysis of the risk or form of persecution, recognition of gender-related persecution, articulation of the state duty to protect against persecution by Non-state actors, the need to limit of the application of internal flight alternative, and the scope of the non-refoulement principle.

\section{A. Guideline on Membership of a Particular Social Group}

Article 1(A) of the 1951 Convention on the Status of Refugees sets forth that a person may be considered a refugee if he/she has a risk of persecution which has a nexus to one of five protection categories: race, religion, nationality, political opinion, or membership of a particular social group. ${ }^{20}$ The protection category of "membership of a particular social group" has proved to be claimed by persons facing discrimination in different contexts, such as relating to socio-economic class, sexual orientation, occupation, family background, etc. The Guideline on "membership of a particular social group" cites only one national case from the High Court of Australia addressing whether the fear of persecution by forcible sterilisation pursuant to China's "One Child Policy" was legitimate to define the particular social group. ${ }^{21}$ Nevertheless, Volker Türk states that the Guidelines sought to reconcile two approaches arising from common law jurisdictions - protected characteristics and social perception-therefore, the absence of the case references is surprising. ${ }^{22}$ The paper did not refer to any cases from the international courts/tribunals/committees.

20 Convention Relating to the Status of Refugees, supra note 1, at 14.

21 UNHCR, Guidelines on International Protection No. 2: "Membership of a particular group" within the context of Article $1 A$ (2) of the 1951 Convention and/or the 1967 Protocol relating to the Status of Refugees, ๆ 14, U.N. Doc. HCR/GIP/02/02 (May 7, 2002) (citing Applicant A. v Minister for Immigration and Ethnic Affairs (1997) 190 CLR 225 (Austl.)).

22 See Türk, supra note 3, at 304. 


\section{B. Guideline on Child Asylum Claims}

At present, children constitute forty-one percent of the world refugee population. ${ }^{23}$ They have received much attention recently due to the precarious situation of Syrian children and the Central American children crossing the border into the United States. ${ }^{24}$ The Guideline on child asylum claims contains citations of Canadian case law (11), United States case law (8), Australian case law (7), United Kingdom case law (4), New Zealand case law (3), French case law (3), and Belgian case law (1). ${ }^{25}$ There is a clear dominance of cases from common law jurisdictions.

However, when we turn to the international level, there is a majority of citations of the Inter American Court of Human Rights as opposed to the European Court of Human Rights. The Guideline cites the jurisprudence of the Inter-American Court of Human Rights in order to underscore the risk or form of persecution such as that facing street children who may be subjected to violence or murder as part of "social cleansing." 26 The Guideline additionally relies on the Inter-American Court of Human Rights to ground the perspective that persecution may be established where children with disabilities or stateless children lack access to birth registration and are excluded from education, health care, and other services. ${ }^{27}$ Further, it referred to an Advisory Opinion by the Inter-American Court to support the call for assessment as to whether or not the State or its agents is unable or unwilling to protect children against

23 Refugees: The Numbers, UNITED NATIONS, http://www.un.org/en/globalissues/briefingpapers/ refugees/ (last visited Jan. 6, 2015).

24 See Nick Cumming-Bruce, U.N. Warns of Lasting Harm to Syrian Refugee Children, N.Y. TIMES, Nov. 29, 2013, at A7; Frances Robles, Fleeing Gangs, Children Flee to the Borders, N.Y. TIMES, July 9, 2014, at A1.

25 See generally UNHCR, Guidelines on International Protection No. 8: Child Asylum Claims under Article 1A(2) and 1(F) of the 1951 Convention and/or the 1967 Protocol relating to the Status of Refugees, U.N. Doc. HCR/GIP/09/08 (Dec. 22, 2009).

26 Id. 12 n.28 (citing Villagrán-Morales et al. v. Guatemala (The "Street Children" Case), Inter-Am. Ct. H.R. (ser. C) No. 77, \ๆ 190-91 (Nov. 19, 1999)). "The Court found that there was a prevailing pattern of violence against street children in Guatemala .... The Court noted that the State had violated their physical, mental, and moral integrity as well as their right to life and also failed to take any measures to prevent them from living in misery, thereby denying them of the minimum conditions for a dignified life." Id.

27 Id. $\$ 36$ n.84. "Two girls of Haitian origin were denied the right to nationality and education because, among other matters, they did not have a birth certificate." See id. (citing The Yean and Bosico Children v. The Dominican Republic, Inter-Am. Ct. H.R. (ser. C) No. 130 (Sept. 8, 2005)). "The Court found that failure to provide severely marginalized groups with access to basic health-care services constitutes a violation of the right to life." See id. (citing Case of the "Juvenile Reeducation Institute" v. Paraguay, Inter-Am. Ct. H.R. (ser. C) No. 112 (Sept. 2, 2004)). 
persecution by non-State actors (such as gangs, parents, etc. ${ }^{28}$ The Guideline also refers to both the Inter-American Court of Human Rights and European Court of Human Rights' contentious case articulation of an obligation of states to conduct effective investigation and punishment of non-state persecutors. ${ }^{29}$ The Guideline also cites case law of the European Court of Human Rights to explain how children may have a well-founded fear of persecution if they have witnessed violence or experienced the disappearance or killing of a parent or other person on whom the child depends. ${ }^{30}$ It turns to the European Court of Human Rights to underscore limits against the application of internal flight alternatives to children, as this may result in inhuman treatment. ${ }^{31}$

Finally, the Guideline refers to the Special Court for Sierra Leone's conclusion "that the recruitment of children under the age of 15 years into the armed forces constitutes a crime under general international law." international citations demonstrate a reverse dominance of the South because of the specialized jurisprudence applicable to child protection.

\section{Guideline on Sexual Orientation and/or Gender Identity}

There have been a series of judicial decisions defending the rights of lesbian, gay, bisexual, and transgender (LGBT) persons at national and international levels. ${ }^{33}$ This has impacted refugee law, and UNHCR itself has intervened in both national and international cases. ${ }^{34}$ The Guideline on sexual orientation and/or gender identity contains more citations of common law:

28 Id. $\mid 37 \mathrm{n} .89$ (citing Advisory Opinion on Juridical Condition and Human Rights of the Child, Advisory Opinion OC-17/02, Inter-Am. Ct. H.R. (ser. A) No. 17 (Aug. 28, 2002)).

29 Id. \38 n.90 (citing Velásquez Rodríguez Case, Inter-Am. Ct. H.R. (ser.C.) No. 4, ๆ 174 (Dec. 3, 2003) and M.C. v. Bulgaria, 2003-XII Eur. Ct. H.R. 1).

30 Id. 17 n.35 (citing Cicek v. Turkey, App. No. 67124/01, EuR. CT. H.R. ๆף 173-74 (Jan. 18, 2005), http:/hudoc.echr.coe.int/sites/eng/pages/search.aspx?i=001-59219 and Bazorkina v. Russia, App. No. 69481/01, Eur. Ct. H.R. ๆף 140-41, http://hudoc.echr.coe.int/sites/eng/pages/search.aspx?i=001-76493 (July 27, 2006)).

31 Id. 56 n.113 (citing Mubilanzila Mayeka and Kaniki Mitunga v. Belgium, 2006-XI Eur. Ct. H.R. 233). "[This case] concerned the return (not internal relocation) of an unaccompanied five-year old girl. The Court was 'struck by the failure to provide adequate preparation, supervision and safeguards for her deportation', noting further that such 'conditions was bound to cause her extreme anxiety and demonstrated such a total lack of humanity towards someone of her age and in her situation as an unaccompanied minor as to amount to inhuman treatment [violation of article 3 of the European Convention on Human Rights]." Id.

32 Id. 19 n.46 (citing Prosecutor v. Sam Hinga Norman, Case No. SCSL-2004-14-AR72(E), Decision on Preliminary Motion Based on Lack of Jurisdiction (Child Recruitment), 1 甲 52-53 (May 31, 3004)).

33 See generally, Thomas M. Keck, Beyond backlash: Assessing the impact of judicial decisions on LGBT rights, 43 L. \& SOC'Y REV. 151 (2009).

34 Volker Türk, Ensuring Protection to LGBTI Persons of Concern, 25 InT’L J. RefugeE L. 120, 125 (2013). 
United States case law (20 including UNHCR amicus briefs filed in cases), United Kingdom case law (10 including UNHCR amicus briefs filed in cases), Canadian case law (9), Australian case law (9), New Zealand cases (3), French case law (3), Belgian case law (3), German case law (1), and Finnish case law $(1){ }^{35}$

In terms of citation of international cases, the Guidelines turn to the U.N. Human Rights Committee to confirm that the "proscribed grounds of 'sex' and 'other status' contained in the non-discrimination clauses of the main international human rights instruments have been accepted as encompassing sexual orientation and gender identity." ${ }^{36}$ The Guidelines refer to the European Court of Human Rights to establish the risk of harm to transgender persons. ${ }^{37}$ It refers to the International Criminal Courts to ground the view that rape may constitute persecution, noting that "International criminal tribunals in their jurisprudence have broadened the scope of crimes of sexual violence that can be prosecuted as rape to include oral sex and vaginal or anal penetration through the use of objects or any part of the perpetrator's body." ${ }^{\text {I }}$ It also sets forth that rape may constitute torture, citing case law of the European Court of Human Rights. ${ }^{39}$ Additionally, it cites the ICTR to state that rape is also characterized as a violation of dignity. ${ }^{40}$

35 See UNHCR, Guidelines on International Protection No. 9: Claims to Refugee Status based on Sexual Orientation and/or Gender Identity within the context of Article 1A(2) of the 1951 Convention and/or its 1967 Protocol relating to the Status of Refugees, U.N. Doc. HCR/GIP/12/09 (Oct. 23, 2012).

36 Id. 6 (citing Human Rights Committee, Toonen v. Australia, U.N. Doc. CCPR/C/50/D/488/1992 (Apr. 4, 1994). "The U.N. Human Rights Committee held in 1994 in the landmark decision Toonen v. Australia that the International Covenant on Civil and Political ... prohibits discrimination on the grounds of sexual orientation." Id. 16 n. 11 .

37 Id. $\uparrow 10$ n.25 (citing Goodwin v. United Kingdom, 2002-VI Eur. Ct. H.R. 1). "The European Court of Human Rights has established that authorities must legally recognize the altered gender. [The Court in Goodwin found] a violation of the applicant's right to privacy, noting that 'the stress and alienation arising from a discordance between the position in society assumed by a post-operative transsexual and the status imposed by law which refuses to recognize the change of gender cannot, in the Court's view, be regarded as a minor inconvenience arising from a formality []', and that 'Under Article 8 of the Convention in particular, the notion of personal autonomy is an important principle underlying the interpretation of its guarantees, protection is given to the personal sphere of each individual, including the right to establish details of their identity as individual human beings"” (citations omitted). Id.

38 Id. $\mid 20$ (citing Prosecutor v. Anto Furundzija, Case No. IT-95-17/1-T, Trial Judgment (Int'1 Crim. Trib. for the Former Yugoslavia Dec. 10, 1998 and Prosecutor v. Dragoljub Kunarac, Radomir Kovac and Zoran Vukovic, Case. No. IT-96-23 \& IT-96-23/1-A, Appeals Judgment, 128 (Int'l Crim. Trib. for the Former Yugoslavia June 12, 2002)).

39 Id. (citing Aydin v. Turkey, 1997-VI Eur. Ct. H.R. 1866).

40 Id. (citing Prosecutor v. Jean-Paul Akayesu, Case No. ICTR-96-4-T, Judgment, ๆ 687 (Sept. 2, 1998)). 
The Guidelines refer to the U.N. Committee on the Elimination of Discrimination against Women (CEDAW) to discuss corrective surgery as persecution. ${ }^{41}$ Moreover, they cite the U.N. Working Group on Detention to support the view that,

[D]etention, including in psychological or medical institutions, on the sole basis of sexual orientation and/or gender identity is considered in breach of the international prohibition against the arbitrary deprivation of liberty and would normally constitute persecution. ${ }^{42}$

The Guideline further notes that U.N. Human Rights Committee and the Inter-American Commission on Human Rights have concluded that the inaction of State vis-à-vis death threats constitutes a violation of the right to life. Additionally, it notes the discriminatory nature of criminal penalties against same sex consensual relations. ${ }^{43}$ This Guideline also refers to secondary sources containing jurisprudence. ${ }^{44}$ In sum, the Guideline appears to refer to both common law and international jurisprudence to pursue an expansive approach to LGBT protection. The citation of international jurisprudence does not serve to "excuse" the one-sided bias of citation of common law; this is because international case law is fundamentally different from national case law. It is inappropriate to argue that legal pluralism or universality in representation is achieved indirectly because the international bodies contain persons of different nationalities and jurisdictions. There is a need for balance in citation of national case law.

\section{Guideline on Claims related to Military Service}

There is no issue that tests the limit of state sovereignty upon the individual as much as that of compulsory military service. Refugee flows often include

41 Id. $\mid 21$ ("The assessment needs to focus on whether the surgery or treatment was voluntary and took place with the informed consent of the individual.") (citing Committee on the Elimination of Discrimination Against Women, para. 11.3, U.N. Doc. CEDAW/C/36/D/4/2004 (Jan. 9, 2015)), "[The] UN Committee on the Elimination of Discrimination against Women (CEDAW) ... considered non-consensual sterilization as a violation of women's rights to informed consent and dignity." Id. ๆ $21 \mathrm{n} .48$.

42 Id. $\mid 22$ (citing Working Group on Arbitrary Detention, Human Rights Council, U.N. Doc. A/HRC/16/47, GAOR, 16th Sess. (Jan. 19, 2008).

43 Id. $\mid 26$ (noting that in Toonen v. Australia the sodomy law of the territory concerned violated the rights to privacy and "equality before the law"). Id. ๆ 26 n.60 (citing Human Rights Committee, Toonen v. Australia, U.N. Doc. CCPR/C/50/D/488/1992 (Apr. 4, 1994).

44 Id. 2 n.4 (citing International COMmission of JuRists, SEXUAL ORIENTATION AND Gender IDENTITY IN HUMAN RIGHTS LAW (4th ed. 2010); INTERNATIONAL COMMISSION OF JURISTS, SEXUAL ORIENTATION AND GENDER IDENTITY IN HUMAN RIGHTS LAW (July 2007) and INTERNATIONAL COMMISSION OF JURISTS, SEXUAL ORIENTATION AND GENDER IDENTITY IN HUMAN RigHTS LAW (Oct. 2007). 
soldiers, some of whom are deserters, and others who claim conscientious objection. ${ }^{45}$ The Guideline on claims related to military service cites only two United Kingdom. cases. ${ }^{46}$ Thus, it excludes review of other national jurisprudence, albeit indirect reference is made via the international cases, which address other countries, such as Armenia, Finland, France, the Netherlands, Turkey, and Korea. At the international level, there are citations from the European Court of Human Rights (5), the ICJ (1), Inter-American Commission of Human Rights (3), the U.N. Human Rights Committee (11), the ICC (1), the U.N. Working Group on Arbitrary Detention (1), and the Special Court for Sierra Leone (2). ${ }^{47}$

These guidelines were eviscerated by Guy Goodwin-Gill, who noted that UNHCR needed to "closely analyse and understand, even if they do not adopt, the reasoning and approaches of national and international courts.... combining 'best law' with progressive development." ${ }^{, 48} \mathrm{He}$ criticized the guidelines for failing to cite an appeals decision by the House of Lords and accepting the views of the U.N. Human Rights Committee over the jurisprudence of the European Court of Human Rights. ${ }^{49}$ The Guidelines point out that,

[t]he UN Human Rights Committee's [HRC] case law has shifted from characterizing the right as derived from the right "to manifest" one's religion or belief and thus subject to certain restrictions in Article 18(3) [of the ICCPR] to viewing it as one that "inheres in the right" to freedom of thought, conscience and religion in Article 18(1) itself. ${ }^{50}$

Specifically, Article 18 of the ICCPR provides:

\footnotetext{
45 See Cecilia Bailliet, Assessing Jus ad Bellum and Jus in Bello within the Refugee Status Determination Process: Contemplations on Conscientious Objectors Seeking Asylum, 20 GEO.IMMIGR. L.J. 337, 338 (2006).

46 UNHCR, Guidelines on International Protection No. 10: Claims to Refugee Status related to Military Service within the context of Article 1A (2) of the 1951 Convention and/or the 1967 Protocol relating to the Status of Refugees, q 31 n.57, 51 n.81, U.N. Doc. HCR/GIP/13/10/Corr. 1. (Nov. 12, 2014) [hereinafter Guidelines on Military Service] (citing Yasin Sepet, Erdem Bulbul v. Secretary of the State for the Home Department, [2001] EWCA CIV 681 (Eng.) and The Queen on the Application of M v. Secretary of State for the Home Department, [2012] EWHC 2552 (Eng.)).

47 See generally id.

48 Goodwin-Gill, supra note 17 , at $657-58$.

49 Id. at 659.

50 Guidelines on Military Service, supra note 46, ๆ 8 (citing Human Rights Committee, Atasoy and Sarkut v. Turkey, U.N. Doc. CCPR/C/104/D/1853-1854/2008 (June 19, 2012) and Human Rights Committee, Min-Kyu Jeong at al v. Republic of Korea, U.N. Doc. CCPR/C/101/D/1642-1741/2007 (Apr. 27, 2011)).
} 
1. Everyone shall have the right to freedom of thought, conscience and religion. This right shall include freedom to have or to adopt a religion or belief of his choice, and freedom, either individually or in community with others and in public or private, to manifest his religion or belief in worship, observance, practice and teaching.

3. Freedom to manifest one's religion or beliefs may be subject only to such limitations as are prescribed by law and are necessary to protect public safety, order, health, or morals or the fundamental rights and freedoms of others.

The Guideline further states that

This is a significant shift, albeit it has been subject to individual concurring opinions. According to the $\mathrm{HRC}$, the right therefore "entitles the individual to an exemption from compulsory military service if this cannot be reconciled with the individual's religion or beliefs. The right must not be impaired by coercion." 52

The Guidelines may be considered to potentially support the crystallization the right of conscientious objection under international law. ${ }^{53}$ This is particularly delicate because one of the consultants for the Guidelines was Rachel Brett, of the Quaker U.N. Office. ${ }^{54}$ She is a well-respected human rights scholar but she also promotes the Quaker aspiration to attain recognition of a right of conscientious objection within international law and thus may be considered a "norm entrepreneur." ${ }^{55}$ Hence, it is essential that the Guidelines contain proper citation of relevant national and international jurisprudence in order to avoid misrepresentation of the law. ${ }^{56}$ The Guidelines are intended to reflect the actual state of law and practice, rather than promoting de lege ferenda.

51 International Covenant on Civil and Political Rights art. 18, Dec. 19, 1966, 999 U.N.T.S. 171.

52 Guidelines on Military Service, supra note 46, $\mid 18$.

53 On the phenomenon of crystallization in law, see generally Michael P. Scharf, Seizing the Grotian Moment: Accelerated Formation of Customary International Law in Times of Fundamental Change, 43 CORNELL INT'L L.J. 439 (2010).

54 The present author also served as a consultant for the unpublished background papers produced for the Guidelines.

55 See generally RACHEL BRETT, QUAKER UN OFFICE, INTERNATIONAL STANDARDS ON CONSCIENTIOUS OBJECTION TO MILITARY SERVICE, (2011), available at http://www.eak-online.de/sites/default/files/Quaker\% 20United\%20Nations\%20Office\%20-\%20Conscientious\%20Objection\%202011.pdf; Jeremy K. Kessler, The Invention of a Human Right: Conscientious Objection at the United Nations, 1947-2011, 44 CoLUM. HuM. RTS. L. REV. 753 (2013). On norm entrepreneurs, see generally Martha Finnemore \& Kathryn Sikkink, International Norm Dynamics and Political Change, 52 INT'L ORGANIZATION 887 (1998).

56 It should be noted that Goodwin-Gill's concern for the lack of citation of the United Kingdom House of Lords decision may be given lesser weight as the legitimacy issue is not resolved only by adding additional common law cases. Instead, I suggest that more attention should be placed on tracing the transnational judicial 


\section{TRANSNATIONAL JUDICIAL DIALOGUES}

There is significant diversity in the interpretation of the 1951 Convention by national tribunals, ranging from variances in the interpretation of "membership in a particular social group," assessment of cases originating from civil wars, recognition of persecution by non-state agents or genderrelated persecution, application of exclusion and cessation clauses, and diverse conceptions of "effective protection by the state," as well as criteria for return due to an internal flight alternative in the country of origin. ${ }^{57}$ North \& Chia observe "[e]ven within the 'harmonized' European Union, recognition rates for Iraqi refugees in 2007 ranged from 0 per cent in Greece and Slovakia to 97 per cent in Hungary." 58 This underscores the importance of guidance by the UNHCR in terms of articulating universal protection standards.

Nevertheless, I suggest that more attention needs to be paid to the evolution of the transnational judicial dialogue within refugee law. Specifically, there should be increased reference to national cases within UNHCR Guidelines in order to illuminate developments within jurisprudence and its impact on refugee law theory. As an example one may consider the assessment of deserters who escape conscription within the Army and seek asylum abroad and the issue as to whether the desertion itself may be considered to ground a finding of a risk of persecution on account of imputed political opinion. The UNHCR Guidelines on International Protection address this issue in Paragraph 52 without reference to national case law:

Depending on the facts, an objection to military service... may be viewed through the prism of actual or imputed political opinion. In relation to the latter, the authorities may interpret the individual's opposition to participating in a conflict or in act(s) as a manifestation of political disagreement with its policies. The act of desertion or evasion may in itself be, or be perceived to be, an expression of political views. $^{59}$

This perspective was reflective of a decision issued by the Australian RRTA which held that:

\footnotetext{
dialogues addressing particular protection issues and normative interpretive questions within refugee law, as is discussed in the next section.

57 See, e.g., North \& Chia, supra note 13, at 224.

$58 I d$.

59 UNHCR, Guidelines on International Protection No. 10: Claims to Refugee Status related to Military Service within the context of Article $1 A$ (2) of the 1951 Convention and/or the 1967 Protocol relating to the Status of Refugees, 9 52, U.N. Doc. HCR/GIP/13/10/Corr. 1 (Nov. 12, 2014).
} 
[The applicant's] decision not to return to Eritrea to comply with his military service obligations.... there is a real chance that the applicant will face persecution in Eritrea because an adverse political opinion will be attributed to him by the authorities and the government. ${ }^{60}$

France and Switzerland also upheld desertion as imputed political opinion within their case law. ${ }^{61}$ Contrary to the Israeli Population, Immigration and Border Authority articulated that they granted only two Eritrean deserters asylum because of their additional political engagement, thereby not relying on the desertion as imputing political opinion by itself. ${ }^{62}$

Switzerland later enacted emergency amendments to its Asylum Act in 2012, setting forth that "persons who are subject to serious disadvantages or have a well-founded fear of being exposed to such disadvantages because they have refused to perform military service or have deserted are not refugees."63 As a result of the change, the Federal Administrative Tribunal has refused to examine refugee claims on the basis of desertion. ${ }^{64}$ UNHCR complained that this constituted a derogation of the 1951 Convention on the Status of Refugees. ${ }^{65}$ Hence, there is disagreement among jurisdictions on this point, and it is suggested that the Guidelines would have benefitted from illuminating this. Ironically, these Guidelines were published in part in order to respond to the legislative amendment, thus it is problematic that there is no reflection within the Guidelines of the counter perspective taken by the state. ${ }^{66}$ Instead of

60 1103210, [2011] RRTA 382 (Austl.), available at http://www.austlii.edu.au/au/cases/cth/RRTA/2011/ 382.html.

61 See Swiss asylum procedure to be tightened, SwISSINFO.CH, http://www.swissinfo.ch/ger/schweizerasylverfahren-soll-verschaerft-werden/7151286 (last visited Feb. 17, 2016); Cour National du droit d'asile [CNDA] [National Court of Asylum] Eritrea, CE, Dec. 23, 2011, Rec. Lebon 11018030 C+ (Fr.) (recognizing an Eritrean deserter as a refugee due to a threat of persecution on account of his imputed political opinion); see also Cour National du droit d'asile [CNDA] [National Court of Asylum] Eritrea CE, Feb. 28, 2012 Rec. Lebon 11015298 (Fr.) (stating that the Eritrean deserter and his wife were granted asylum on account of imputed political opinion).

62 See Ilan Lior, Two Eritreans Granted Refugee Status in Rare Decision, HAARETZ (Jan. 27, 2014, 1:08 AM), http://www.haaretz.com/news/national/.premium-1.570737.

63 Asylgesetz [AsylG] [Asylym Act] June 26, 1998, 142.31, art. 3 (Switz.).

64 See inter alia, Tribunal administratif fédéral [TAF] [Federal Administrative Court] D-6729/2009, Feb. 14, 2013, 2.4 (Switz.); Tribunal administratif fédéral [TAF] [Federal Administrative Court] E-7185/2013, Feb. 19, 2014, 93.3 .2 (Switz.).

65 See Switzerland UNHCR's Position on the Amendment of the Law on Asylum (June 6, 2012), http://www.unhcr.ch/fileadmin/user_upload/unhcr_ch/Recht/Brief-NR20120530F.pdf.

66 Another example of contradictory national legislation is that of Australia, which narrows the definition of 'persecution' to require reasons for persecution to be 'essential and significant for the persecution' and that the persecution involve serious harm to the persons and systematic and discriminatory conduct. Australian 
ignoring discrepancies in national protection standards, it would be preferable for UNHCR to identify them and respond directly within its Guideline citations in order to ensure proper understanding of the evolution of refugee law.

There are also examples of national case law which may give an expanded scope of protection beyond the 1951 Convention, such as the South African Refugee Act of 1998, which incorporates the wider refugee definition provided by the OAU Refugee Convention. ${ }^{67}$ In Katabana v. the Chairperson of the Standing Committee for Refugee Affairs and Others, the South African High Court granted refugee status to an asylum seeker from the DRC who claimed fear of persecution on the grounds of religion and a total breakdown of law in the DRC. ${ }^{68}$ The Court found the Refugee Status Determination Officer's rejection to be "unjustifiable" considering the evidence given and the lack of reasons provided for justifying the refusal: "[a]fter three years to simply say 'you have to go back' to a country where the conditions are so obviously supportive of this claim for refugee status is not just nor compatible with the Act. ${ }^{" 69}$ This, in turn, is supported by those Refugee Law scholars who have used references to pluralistic sources in order to expand our understanding of the non-refoulement principle beyond the 1951 Convention. ${ }^{70}$

It is interesting that UNHCR actually produced specific Eligibility Guidelines for Assessing the International Protection Needs of Asylum Seekers from Eritrea (UNHCR April 2009) which also advocate the position that "even where a claim is not based on actual political opinion, or not perceived by the draft evader or deserter as being an expression of political opinion, refusal to perform military service may nevertheless amount to imputed political opinion.. ${ }^{, 71}$ It further argues that:

Lawyers for Human Rights Refugee Kit: Australia's Refugee Law, AUSTRALIAN LAWYERS FOR HUMAN RIGHTS, http://www.alhr.asn.au/refugeekit/downloads/chapter_3.pdf (last updated Nov. 30, 2004).

67 Refugee Act 130 of 1998 (S. Afr.).

68 Katabana v. Chairperson of the Standing Committee for Refugee Affairs, et al. 2012 ZAGPPHC 362 (S. Afr.).

69 Id.; see also Harerimana v. the Chairperson of the Refugee Appeal Board and Others 2014 (5) SA 550 (WCC) (S. Afr.) (granting refugee status to an asylum seeker from Burundi, overturning the decision of the Refugee Status Determination Officer which failed to recognize flight from "disturbing or disrupting public order" as grounds for protection).

70 See Sir Elihu Lauterpacht QC \& Daniel Bethlehem, The Scope and Content of the Principle of NonRefoulement: Opinion, in ReFugee Protection In InTERnATIONAL LAw 81, 125 (Erika Feller, Volker Türk \& Frances Nicholson eds., Cambridge Univ. Press ed.2003). Refugee Protection in International Law, supra note 3 , at 125 .

71 U.N. High Comm'r for Refugees, UNHCR Eligibility Guidelines for Assessing the International Protection Needs of Asylum-Seekers from Eritrea 16 (Apr. 2009). 
[m]ilitary service has become politicized in Eritrea and actual or perceived evasion or desertion from military service is regarded by the Eritrean authorities as an expression of political opposition to the regime. Persons who evade or desert military service are regarded as disloyal and treasonous towards the Government and are punished for their perceived disloyalty. Hence, persons of, or approaching, military service age, who are medically fit, are at risk of persecution on return to Eritrea as actual or perceived draft evaders or deserters on the ground of imputed political opinion. ${ }^{72}$

This section actually cites case law from Australia, New Zealand, and Canada. ${ }^{73}$ It is suggested that reference to these cases would have been positive for the UNHCR Guidelines on Military Service (although they are all common law cases), and it is curious that they were omitted. As a point of clarification, it should be noted that the UNHCR Refworld database contains a significant collection of jurisprudence that goes beyond the case citations in the guidelines and this is fully accessible to asylum adjudicators, including UNHCR staff. ${ }^{74}$

On a related issue, regarding the degree of risk of involvement in war crimes that a soldier has to show in order to receive protection, in Germany in 2011, the Federal Bureau of Migration and Refugees initially rejected the asylum application of an American Deserter, Andre Shepherd, who did not want to deploy to Iraq. ${ }^{75}$ The Munich Administrative Court sent a request to the Court of Justice of the European Union to examine "the degree to which an involvement in military hostilities is necessary, in order to offer the right of

72 Id. at $16-17$.

73 U.N. High Comm'r for Refugees, UNHCR Eligibility Guidelines for Assessing the International Protection Needs of Asylum-Seekers from Eritrea 16 (Apr. 2009) (citing Erduran v Minister for Immigration \& Multicultural Affairs [2002] FCA 814, (Unreported, Gray J., June 27, 2002) (Federal Court of Australia) (Austl.); Zolfagharkhani v. Canada (Minister of Employment and Immigration), [1993] 3 F.C. 540 (Can. Federal Court of Appeal); Refugee Appeal No. 75378 [2005] New Zealand Refugee Status Appeals Authority (NZRSAA) 314 (Oct. 19, 2005), para. 116 (N.Z.); and Refugee Appeal No. 76183 [2008] New Zealand Refugee Appeals Authority (NZRSAA) 41 (May 13, 2008), paras. 50-51 (N.Z.)).

74 UNHCR Case Law, REFWORD, http://www.refworld.org/type,CASELAW,,,,, 0. html (last visited Dec. 29, 2014). In addition, there are other refugee law databases that collect jurisprudence. See REFLAW, http:// www.reflaw.org (last visited Dec. 29, 2014); IARLJ Database, INTERNATIONAL AsSOCIATION OF REFUGEE LAW JudGES, http://www.iarlj.org/general/database (last visited Dec. 29, 2014); Search Asylum Case Outcomes, U.C. HASTINGS CENTER FOR GENDER AND REFUGEE STUDIES, http://cgrs.uchastings.edu/searchcases (last visited Dec. 29, 2014). Nevertheless, these databases contain a majority of case law from the developed countries as opposed to developing countries. Moreover, even in the case of inclusion of a case from a developing country it is more likely to be a common law, English language decision.

75 See Major Christian L. Deichert, Is Germany the New Canada? One American Deserter's request for Asylum in Germany, 205 MiL. L. REV. 94, 95 (2010); see also Kevin Dougherty, U.S. Army Deserter denied Asylum by Germany, STARS AND STRIPES (April 5, 2011), http://www.stripes.com/u-s-army-deserter-deniedasylum-by-germany-1.140098. 
refugee status to a military deserter, who will be punished for his desertion". 76 This is referring to the European Council Directive 2004/83/EC which recognizes grounds for protection "for refusal to perform military service ... where performing military service would include crimes or acts failing under the exclusion clauses as set out in Article 12(2).",77 Paragraph 28 of the UNHCR Guidelines on Military Service sets forth that "it is the risk of being compelled to become involved in the act(s), rather than the conflict alone that is at issue, so the individual circumstances of the applicant must thus be examined, bearing in mind the role in which he or she will be engaged." 78

The European Court of Justice issued a judgment on February 26, 2015 in which it held that Article 9 encompasses all military personnel, including logistical or support personnel, that it addresses situations in which military service would include the commission of war crimes (even if the applicant would participate indirectly if it is reasonably likely that he would prove indispensable support to the preparation or execution of those crimes), and that it does not exclusively concern situations in which it is established that war crimes have already been committed or would fall within the jurisdiction of the ICC's jurisdiction, but also those in which the applicant can establish that it is highly likely that such crimes will be committed. ${ }^{79}$ The Court further concluded that the national authorities would have to carry out a factual assessment of the situation of the military service, also taking into account whether the military intervention was pursuant to a UN Security Council mandate or consensus on the part of the international community, or that the state or states conducting the operations prosecute war crimes. Finally, the Court set forth that refusal to perform military service must be the only means by which the applicant could avoid participating in war crimes.

76 Press Release, Pro Asyl, AWOL Soldier at the European Court of Justice (June 9, 2013), available at http://www.proasyl.de/en/press/press/news/awol_us_soldier_at_the_european_court_of_justice/.

77 Council Directive 2004/83/EC, art. 9, 2004 O.J. (L 304/12). Article 12(2) lists various refugee exclusions. Council Directive 2004/83/EC, art. 12(2), 2004 O.J. (L 304/12). Particularly, Article 12(2) excludes a person from refugee status where there is evidence that the individual "has committed a crime against peace, a war crime, or a crime against humanity, as defined in the international instruments drawn up to make provision in respect of such crimes." Council Directive 2004/83/EC, art. 12(2)(a), 2004 O.J. (L 304/12).

78 UNHCR, Guidelines on International Protection No. 10: Claims to Refugee Status related to Military Service within the context of Article $1 A$ (2) of the 1951 Convention and/or the 1967 Protocol relating to the Status of Refugees, 928 , U.N. Doc. HCR/GIP/13/10/Corr. 1 (Nov. 12, 2014).

79 Shepherd v. Bundesrepublik Deutschland, 2015 E.C.R., http://curia.europa.eu/juris/document/ document.jsf?text=\&docid=162544\&pageIndex=0\&doclang=en \&mode=req \&dir=\&occ=first \&part=1\&cid=26 0825 . 
The next section addresses whether UNHCR Background Papers contain similar common law bias to the UNHCR Guidelines.

\section{UNHCR BACKGROUND NOTES/PAPERS}

Six UNHCR guidelines do not include any references to national case law: gender-related persecution, cessation of refugee status, internal flight alternative, exclusion clauses, religion-based claims, and victims of trafficking. Hence, it is necessary to review the background notes/papers produced for the guidelines. Background papers are commissioned from individual refugee law experts and therefore present the position of that consultant. It is noted that

[s]ometimes a paper advocates one particular interpretation rather than a range of approaches which may exist. The papers do not therefore purport to be a definitive position, but rather are part of a process of taking the debate forward on key issues of interpretation on which opinion and jurisprudence continue to differ. ${ }^{80}$

The background paper on cessation of refugee protection does not refer to any case law, relying instead on a rich collection of interviews, UNHCR and UN policy materials, and national administrative and legislative sources. ${ }^{81}$ The paper would be strengthened by reference to cases that have examined terminology within Article 1(C), such as "changed circumstances" or the "compelling reasons" exception. ${ }^{82}$

The background paper on claims for protection on religion or belief states clearly that reference to jurisprudence is limited to the United States, Canada, New Zealand, and United Kingdom. ${ }^{83}$ The citations are indeed a thorough collection of common law decisions: United States (28), United Kingdom (22),

80 See Volker Türk \& Frances Nicholson, Refugee Protection in International Law: An Overall Perspective, in Refugee Protection In International LaW 3, 8 (Erika Feller, Volker Türk \& Frances Nicholson eds., 2003).

81 See Joan Fitzpatrick \& Rafael Bonoan, Cessation of Refugee Protection, in REFUGEE PROTECTION IN InTERNATIONAL LAW 492 (Erika Feller, Volker Türk \& Frances Nicholson eds., Cambridge Univ. Press ed. 2003).

82 See Roger Errera, Cessation and Assessment of New Circumstances: a Comment on Abdulla, CJEU, 2 March 2010, 23 INT'L J. ReFugEe L. 521 (2011); see also Yong-Guieco v. Canada (Minister of Immigration and Citizenship), [1997] Federal Court of Canada, Trial Division (July 14, 1997).

83 Karen Musalo, Claims for Protection Based on Religion or Belief: Analysis and Proposed Conclusions 9, U.N. Doc. PPLA/2002/01 (U.N. High Comm'r for the Refugees Dep't of Int'1 Prot., Dec. 2002). 
New Zealand (37), and Canada (33). ${ }^{84}$ However, this is problematic in particular given the special nature of the topic which behoves a more universal perspective, including civil law cases and international jurisprudence. ${ }^{85}$

Similarly, the background paper on Gender-related persecution contains citations of common law cases from the United States (3), United Kingdom (9), Australia (5), and New Zealand (6) ${ }^{86}$ Unfortunately, the paper contains only one footnote which recommends secondary literature by Walter Kälin for "discussion of the French, German and Swiss law" regarding the interpretation of a "well-founded" fear of persecution. ${ }^{87}$ Nevertheless, as pertaining the international level, it refers to cases from ICTR (1) and ICTY (1). Specifically, the paper cites the ICTR, Prosecutor v. Jean-Paul Akayesu, which defines rape in international law and holds that rape can constitute genocide, and the ICTY, Prosecutor v. Kunarac, Kovac and Vukovic. ${ }^{88}$

There is improvement in the background note on membership of a particular social group which contains references to cases from both common law and civil law jurisdictions: the United States (17), France (18), Australia (5), Germany (5), United Kingdom (3), New Zealand (3), the Netherlands (1), and Canada (1). ${ }^{89}$

National adjudicators increasingly recognize the existence of an "internal flight alternative" in order to limit access to asylum. ${ }^{90}$ There is concern that there are procedural and substantive errors made in this type of analysis, and hence there is a need for protection guidance. ${ }^{91}$ The background paper on

84 See generally Karen Musalo, Claims for Protection Based on Religion or Belief: Analysis and Proposed Conclusions, U.N. Doc. PPLA/2002/01 (U.N. High Comm'r for the Refugees Dep't of Int'1 Prot., Dec. 2002).

85 See Hee Eun Lee, Strange Bedfellows? China, Germany, and Religious Liberty, 10 REGENT J. INT'L L. 151 (2014).

86 See generally Roger Haines QC, Gender-related persecution, in REFUGEE PROTECTION IN InTERnATIONAL LAW 320-43 (Erika Feller, Volker Türk \& Frances Nicholson eds., Cambridge Univ. Press ed. 2003).

87 Id. at 338 .

88 Id. at 336 .

89 T. Alexander Aleinikoff, Protected Characteristics and Social Perceptions: An analysis of the Meaning of Membership of a Particular Social Group, in REFUGEe PROTECTION IN INTERNATIONAL LAW 264, 268-85 (Erika Feller, Volker Türk \& Frances Nicholson eds., 2003).

90 See generally Elizabeth Ferris, Internal Displacement and the Right to Seek Asylum, 27 REFUGEE SURV. Q. 76, 77 (2008).

91 See generally Ninette Kelley, Internal Flight/Relocation/Protection Alternative: Is it Reasonable?, 14 InT'L J. RefugeE L. 4 (2002); see also Reinhard Marx, The Criteria of Applying the "Internal Flight Alternative” Test in National Refugee Status Determination Procedures, 14 INT'L J. REFUGEE L. 179 (2002). 
internal flight alternative reveals some improvement, as there is more inclusion of civil law cases, although common law cases remain in the majority: Canada (25), United Kingdom (19), Australia (19), United States (11), New Zealand (9), Germany (10), Switzerland (2), the Netherlands (7), Austria (1) France (1). ${ }^{92}$ In terms of cases from international jurisdictions, the paper cites the Permanent Court of International Justice (1), European Court of Human Rrights (2), and Committee Against Torture (1). ${ }^{93}$ The paper cites the European Court of Human Rights, Chahal v. United Kingdom establishing that an internal flight alternative is not possible where the State (police) is the persecutor; this is also confirmed in Hilal v. United Kingdom, and by the Committee Against Torture in Alan v. Switzerland. ${ }^{94}$

The application of the exclusion clauses in Article 1(F) of the 1951 Convention relating to crimes against peace, war crimes, crimes against humanity, serious crimes outside the country of refuge, or acts contrary to the purposes and principles of the United Nations the 1951 Convention is one of the most contentious issues within refugee law, in particular due to the escalation of the war on terror after September $11 .^{95}$ It is positive that the background paper on Exclusion contains a majority citation of civil law decisions, in spite of the fact that the author has a common law background himself: Switzerland (10), Canada (3), United Kingdom (3), United States (2), France (3), and Belgium (2). ${ }^{96}$ Further, reference to jurisprudence from the international level includes citations to the judgment of the International Military Tribunal at Nuremberg (1), International Criminal Tribunal for the former Yugoslavia (ICTY) (5), the European Court of Human Rights (2), the U.N. Human Rights Committee (1), and the International Court of Justice (ICJ) (2). ${ }^{97}$ The judgment at Nuremberg and ICTY jurisprudence is cited for

92 James C. Hathaway \& Michelle Foster, Internal protection/relocation/flight alternative as an aspect of refugee status determination, in REFUGEE PROTECTION IN INTERNATIONAL LAW 357, 357-415 (Erika Feller, Volker Türk \& Frances Nicholson eds., 2003).

93 Id.

94 Id. at 395-96.

95 See e.g., Jennifer Bond, Excluding Justice: The Dangerous Intersection between Refugee Claims, Criminal Law, and Guilty Asylum Seekers, 24 Int'1 J. Refugee L. 37-59 (2012).

96 UNHCR, Background Note on the Application of the Exclusion Clauses: Article $1 F$ of the 1951 Convention relating to the Status of Refugees (Sept. 4, 2003), available at http://www.refworld.org/docid/ 3f5857d24.html.

97 Geoff Gilbert, Current Issues in the Application of the Exclusion Clauses, in REFUGEE PROTECTION IN InTERNATIONAL LAW 426, 426-78 (Erika Feller, Volker Türk \& Frances Nicholson eds., Cambridge Univ. Press ed. 2003). 
definition of international crimes. ${ }^{98}$ It cites the European Court of Human Rights to establish the non-refoulement standard and fair trial standards. ${ }^{99}$ On torture, it also cites the European Court of Human Rights and the CAT. ${ }^{100}$ It turns to the ICTY to address the exclusion of underage persons at ICC. ${ }^{101}$ The background paper is thoroughly researched and reveals even citations.

The consultants who produced the background notes for these guidelines tend to come from common law backgrounds and hence this may in part explain the focus on common law cases, although there was one exception. Another worrisome trend, in like manner to the Guidelines, is the complete absence of references to cases from developing countries. At present, through selective citation of national case law, both the soft law UNHCR Guidelines and Background Papers appear to lack the universal characteristic they are intended to have and this requires rectification in order to preserve legitimacy of international law-making.

\section{CONCLUSION}

This Article pursued a deconstruction of the UNHCR Guidelines on International Protection and Background Papers in order to demonstrate the importance of increased pluralistic references to national case law. Change is required in order to ensure that citation of national case law is pursued in all guidelines, and that the bias towards common law judgments - as well as the omission of cases from the developing world-is corrected to avoid the appearance of selectivity in case law. UNHCR's Department of International Protection needs to be expanded in terms of human resources in order to enable it to legitimately fulfill its mandate of providing a truly global assessment of

\footnotetext{
98 Id. (citing Prosecutor v. Akayesu, Case No. ICTR-96-4-T, Trial Judgment (Int'l Crim. Trib. for Rwanda Sept. 2, 1998); Prosecutor v. Kupreskic, Case No. IT-95-16-T, Judgment (Int'l Crim. Trib. for the Former Yugoslavia Jan. 14, 2000); Prosecutor v. Furundzija, Case No. IT-95-17/1-T 10, Judgment (Int'l Crim. Trib. for the Former Yugoslavia Dec. 10, 1998); Prosecutor v. Tadic, Case No. IT-94-1-I, Decision on the Defence Motion for Interlocutory Appeal on Jurisdiction, ๆ 134 (Int'l Crim. Trib. for the Former Yugoslavia Oct. 2, 1995)).

99 Id. (citing Chahal v. United Kingdom, App. No. 22414/93, 23 Eur. H.R. Rep. 415 (1996); Jabari. V. Turkey, 2000-VIII Eur. Ct. H.R. 149 (explaining non-refoulement according to Article 3) Maaouia v. France, 2000-X Eur. Ct. H.R. 273 (explaining the fair trial standard)).

100 Id. (citing Selmouni v. France, App. No. 25803/94, 1999-V Eur. H.R. Rep. 149; Labita v. Italy, 2000IV Eur. Ct. H.R. 25; Mutombo v. Switzerland, Communication No. 13/1993, U.N. Doc CAT/C/12/D/13/1993 (Apr. 27, 1994); Khan v. Canada, Communication No. 15/1994, U.N. Doc CAT/C/13/D/13/1994, 12.2 (Nov. $18,1994))$.

101 Id. (citing Prosecutor v. Drazen Erdemovic, Case No. IT-96-22-A (Int'l Crim. Trib. for the Former Yugoslavia Oct. 7, 1997)).
} 
protection standards as they evolve within refugee law tribunals around the world. It is recommended that the UNHCR Guidelines on International Protection be revised in order to achieve this purpose. Further, since there appears to be no political will to amend the 1951 Convention to recognize and address new forms of forced migration, it is likely that creation of international soft law in the form of guidelines will continue to be a primary means by which to evolve refugee law. ${ }^{102}$ Geoff Gilbert articulates the aspiration that UNHCR is expected to provide universal protection guidance:

In the absence of a treaty monitoring body to hear individual petitions regarding state implementation of the 1951 Convention, the role of UNHCR's Division of International Protection in providing guidance to national decision makers through the guidelines has much greater significance. UNHCR is the only body with a global understanding of refugee status determination as it is carried out by individual states or its own staff in those cases where the state has delegated the function. What might be readily to hand in well-funded courts and tribunals in the global North, may be difficult to access and keep up to date elsewhere; equally, interpretations of the 1951 Convention can be driven by domestic or regional factors that are inappropriate for a universal treaty regime. Thus, the Guidelines on International Protection are an essential guarantee for the individual seeking refugee status. ${ }^{103}$

Nevertheless, as long as the Guidelines have a common law bias in their citations and are devoid of references to cases from the developing world, they cannot be characterized as reflective of universal standards. ${ }^{104}$

UNHCR should be given appropriate funding to strengthen the Department of International Protection in terms of competent staffing and related support. At present it has only seven to eight lawyers and this renders the possibility of properly fulfilling the protection mandate very difficult. Staffing and consultancy should ensure representativeness of civil law traditions as well as common law, in addition to developing country jurisdictions. The Department of International Protection should ensure close citation of national case law in its guidelines and publish compilations of national jurisprudence. UNHCR

102 See generally, Alexander Betts, Towards a 'Soft Law' Framework for the Protection of Vulnerable Irregular Migrants, 22 INT'L J. REFUGEE L. 209 (2010).

103 Geoff Gilbert, Interesting Times: 2002-13, 25 INT'L J. REFUGEE L. 195, 197-98 (2013).

104 It may be argued that there is a parallel situation within refugee law theory, as textbooks within the field also cite more common law and English language national cases than those of civil law, non-English, or developing countries. GuY S. Goodwin-GiLl \& JANE McAdam, The REFugeE in InTERnAtional LaW (3d ed. 2007); James C. Hathaway \& Michelle Foster, The Law of Refugee Status (2d ed. 2014). 
should be given additional funds to enable it to provide translations of key judgments in either English or French (with abstracts in the other language). Greater pluralism in staffing will lead to greater legitimacy. There is also a need for greater transparency of the role of the international civil servants, experts, NGOs, judges, and government officials in soft law evolution; for example, all Background Notes should be published. ${ }^{105}$ Additionally, UNHCR should lobby states to provide access to their asylum case law. Indeed, many jurisdictions limit access to few, select cases from the higher appeals levels. ${ }^{106}$ The lack of openness at the national level limits the evolution of refugee law. This brings to mind the argument by Third World Approaches to International Law (TWAIL) scholars that international law is supportive of a European/Western colonial project. ${ }^{107}$ As long as countries do not render their asylum case accessible they will not be unable to influence or participate in refugee law's evolution. Some scholars are reluctant to encourage developing countries to take over refugee status determination from UNHCR, noting that "[m]any countries that have not set up their own RSD have weak rule of law or problems with judicial independence". ${ }^{108}$ Nevertheless, it is important to recognize that developed states are also increasingly limiting access to their case law and may also be characterized as being subject to political pressure and harboring similar bias against refugees. ${ }^{109}$

105 One may wish to link this to the accountability discussion presented by Volker Türk and Elisabeth Eyster. See Volker Türk \& Elisabeth Eyster, Strengthening Accountability in UNHCR, 22 INT'L J. REFUGEE L. 159-72 (2010).

106 South Africa, for example.

107 See generally, ANTONY ANGHIE, IMPERIALISM, SOVEREIGNTY AND THE MAKING OF INTERNATIONAL LAW (2007). B.S. Chimni stated:

If a serious critique of Refugee Studies, in particular Refugee Law, is not forthcoming it is because the agenda of evolving Refugee Studies is set in the North. All the major centres of Refugee Studies are located in the North. The key journals on refugee issues are published there. ... It is merely to stress the need for scholarship that questions the assumptions that inform dominant strands of Northern thinking with regard to the causes and solutions of refugee flows, and to advance alternative viable models of responsibility sharing and humanitarian assistance. . . The principal locus of knowledge production, in so far as theoretical/methodological knowledge and empirical/descriptive knowledge that is problematic. It has meant that local knowledge, despite the overwhelming consensus on its need, has played a marginal role in shaping Refugee Studies.

B.S. Chimni, The Birth of a 'Discipline': From Refugee to Forced Migration Studies, 22. J. REFUGEE STUD. 11, 16-17 (2009).

108 Michael Kagan, Why is UNHCR Doing RSD Anyway? A UNHCR Report Identifies the Hard Questions, RSD WATCH (Dec. 11, 2014), https://rsdwatch.wordpress.com/2014/12/11/why-is-unhcr-doing-rsdanyway-a-unhcr-report-identifies-the-hard-questions/.

109 For an illuminating account of injustice within the United Kingdom asylum system, see generally Frances WebBer, Borderline Justice: THe Fight For RefugeE AND Migrant Rights (2012). 
UNHCR itself conducts Refugee Status Determination in seventy-five states, including some of the countries with the highest number of refugees, such as Pakistan. ${ }^{10}$ These cases are not publically available and have come under critique, for example for lacking procedural fairness and at times lacking to state the reasons for rejection. ${ }^{111}$ There have been additional complaints regarding the lack of accountability of UNHCR for insufficient interpretation, limited length of interviews of applicants, lack of legal representation provided to applicants, and its immunity from judicial scrutiny. ${ }^{112}$ UNHCR highlights that its procedures are confidential and hence they are unable to share individual cases with third parties, except for very exceptional circumstances. There is a need for transparency as pertaining UNHCR cases as well as national jurisprudence in order to understand and develop the foundation for universal legal protection standards.

At present, UNHCR has confirmed that the developing world hosts eightysix percent of the world's 51.2 million refugees. ${ }^{113}$ One may argue that this underscores the importance of ensuring that refugee law protection standards should include citations from developing countries in order to legitimately claim universal status. It is of concern that the database RefWorld often lacks references to cases from many countries which process a significant number of cases (such as Iran, Pakistan, Venezuela, Kenya, Ethiopia, Chad), irrespective of whether it is UNHCR or the national state conducting the assessment. ${ }^{114}$

110 U.N. High COMM'R FOR REFUgEes, WAR's Human COST: UNHCR GLOBAL TRENDS 2013, at 2 (June 20, 2014), available at http://www.unhcr.org/5399a14f9.html\#_ga=1.228173789.1969792538.1420042541.

111 For a critical review indicating concern for procedural justice, see Maja Smrkolj, International Institutions and Individualized Decision-Making: An Example of UNHCR's Refugee Status Determination, in The Exercise of Public Authority By International Institutions 165-93 (Armin von Bogdandy, Rüdiger Wolfrum, Jochen von Bernstorff, Philipp Dann, Matthias Goldmann, eds., Springer Berlin Heidelberg 2010); see also Procedural Standards for Refugee Status Determination Under UNHCR's Mandate, U.N. High COMM'R FOR REFugeES, (Sept. 1, 2005), http://www.unhcr.org/4316f0c02.html (providing the UNHCR's procedural standards for Refugee Status Determination); António Guterres, Fairness in UNHCR ESD Procedures: Open Letter, 19 INT'L J. REFUGEE L. 161, 161-62 (2007); Michael Kagan, The Beleaguered Gatekeeper: Protection Challenges Posed by UNHCR Refugee Status Determination, 18 INT'L J. REFUGEE L. 1, 1-29 (2006).

112 C, AK, KMF, VK, BF and YAM v. Director of Immigration \& Another [2011] HCAL 132/2008, ๆ 17 (C.A.) (H.K.), available at http://www.refworld.org/docid/4f15310c2.html. In March 2014, Hong Kong took over the asylum screening procedures from UNHCR. See Draft Articles on the Responsibility of International Organizations, [2011] 2 Y.B. Int'1 L. Comm'n 52, U.N. Doc. A/66/10.

113 U.N. High COMM'R FOR REFugeEs, WAR's HuMAN COST: UNHCR Global TRENDS 2013, at 2 (June 20, 2014), available at http://www.unhcr.org/5399a14f9.html\#_ga=1.228173789.1969792538.1420042541.

114 However, UNHCR's engagement with national courts in the form of amicus curiae also largely focuses on common law countries, but does include developing countries: United States 32, United Kingdom 31, Belgium 6, Canada 5, France 6, Germany 7, Greece 10, Italy 5, Iran 8, Netherlands 8, Somalia 11, Afghanistan 11, El Salvador 7, Eritrea 8, Honduras 5. See Court Interventions/Amicus Curiae, ReFWorLD, 
There are three national jurisdictions from the developing world that have the majority of their case law registered within RefWorld: Hong Kong (91 cases), Costa Rica (86 cases, no cases after 2004), and South Africa (76) cases. Among the top three, two are historically Commonwealth countries. Other national jurisdictions are included only sporadically with total numbers in the single digits, and many referring to cases that are taken up by regional or universal human rights bodies.

From a strategic, institutional/organizational perspective; although it may be argued that UNHCR's primary focus is field assistance, addressing immediate protection needs such as providing shelter, water, etc., it is essential to reinvigorate its normative legal protection mandate as well in order to respond to the changing dynamics of forced migration and need for legal guidance in asylum determination. ${ }^{115}$ This requires reform and buttressing of the Department of International Protection and strengthening the process behind the drafting of Guidelines and Background Notes in order to meet the aspiration of developing truly universal protection standards.

http://www.refworld.org/cgi-

$\mathrm{bin} /$ texis/vtx/rwmain?page $=$ type $\&$ type $=$ AMICUS\&publisher $=$ UNHCR\&coi $=\&$ docid $=\&$ skip $=0 \quad$ (last visited Jan. 4, 2015).

115 As noted by Gil Loescher:

Perhaps the most important constraint facing UNHCR results from the shift in focus from legal protection to emergency assistance that has occurred within the agency in recent years. In its first decades the protections of refugees reflected the core values and practices which gave UNHCR its special meaning, identity and coherence. Since the mid 1980 s, as operational activities have gained precedence over protection, UNHCR's culture of protection has declined. Organisational changes have sidelined the Division of International Protection (DIP) in favour of the more pragmatic and operational regional bureaus. This shift in identity has accelerated as humanitarian emergencies have come to be perceived chiefly in terms of logistics and as UNHCR has become identified with providing massive relief to refugees.

Gil Loescher, UNHCR and the Erosion of Refugee Protection, 10 FORCED MIGRATION REV. 28, 28 (2001). 